\title{
Profitability analysis of hotel companies in the Republic of Serbia
}

\author{
Aleks andra Mitrović ${ }^{1}$, Snežana Knežević ${ }^{2}$, Marko Milašinović ${ }^{1 *}$ \\ ${ }^{1}$ University of Kragujevac, Faculty of Hotel Management and Tourism in Vrnjačka Banja, \\ Serbia \\ ${ }^{2}$ University of Belgrade, Faculty of Organizational Science, Belgrade, Serbia
}

\begin{abstract}
The purpose of the research is to examine the level and trends of profitability ratios of hotel companies operating in the Republic of Serbia in the period from 2016 to 2019. The research was conducted on a sample of 100 hotel companies, where profitability was meas ured by the operating profit rate, the net profit rate, the rate of return on total assets and the rate of return on equity. The results of the res earch show that the values of the used profitability indicators have increased in 2017 compared to 2016, but decreased in 2018 and 2019. Statistical analy sis found that changes in the operating profit rate and net profit rate during the observed four-year period were not statis tically significant, while the decline in the value of the rate of return on total assets in 2018 compared to 2017 and the decline in the rate of return on equity in 2018 compared to 2017 and in 2019 compared to 2018 was statis tically significant. The results of the research can be important for (1) the management of a company, (2) its owners, because they enable gaining an insight into the level of profitability of entrusted companies, i.e. the companies that are in the ownership, and (3) investors and creators of tourism development policy.
\end{abstract}

Keywords: profitability, ratio analysis, hotel companies, comparison, Republic of Serbia JEL classification: M41, G30

\section{Analiza profitabilnosti hotelijerskih preduzeća u Republici Srbiji}

Sažetak: Svrha istraživanja je da ispita nivo i kretanje pokazatelja profitabilnosti hotelijers kih preduzeća iz Republike Srbije u periodu od 2016. do 2019. godine. Istraživanje je izvršeno na uzorku od 100 hotelijerskih preduzeća, pri čemu je profitabilnost merena stopom poslovnog dobitka, stopom neto dobitka, stopom prinosa na ukupna sredstva i stopomprinosa na sopstveni kapital. Rezultati istraživanja pokazuju da vrednosti korišćenih pokazatelja profitabilnosti rastu u 2017. u odnosu na 2016. godinu, ali opadaju u 2018. i 2019. godini. Statis tičkomanalizomje utvrđeno da promenes tope poslovnog dobitka istope neto dobitka tokomposmatranog četvorogodišnjeg perioda nisu statistički značajne, dok su pad vrednosti stope prinosa na ukupna sredstva u 2018. u odnosu na 2017. godinu i pad stope

* marko.milasinovic@kg.ac.rs

This article is an open access article distributed under the terms and conditions of the Creative Commons Attribution (CC BY) license (http://creativecommons.org/licenses/by/4.0/). 
prinosa na sopstveni kapital u 2018. u odnosu na 2017. godinu i 2019. u odnosu na 2017. godinu, statistički značajni. Rezultati istraživanja mogu biti od značaja za menadžment preduzeća, kao i za njegove vlasnike, jer omogućavaju sagledavanje nivoa profitabilnosti poverenih preduzeća, odnosno, preduzeća koja se nalaze u njegovom vlasništvu, ali i investitorima i kreatorima politike razvoja turizma.

Ključne reči: profitabilnost, racio analiza, hotelijerska preduzeća, Republika Srbija JEL klasifikacija: M41, G30

\section{Introduction}

Touris m, as an economic activity, combines the activities of production and service of food and beverage, hospitality and transportation (Lee et al., 2019). "The touris m sector represents a significant potential of any national economy" (Milenković et al., 2017, p. 197). The benefits of tourism development for one country are reflected in employment growth, increased foreign exchange inflows (Lee et al., 2019; Milenković et al., 2017; Ren et al., 2019), as well as in the renewal of exis ting catering resources and increasing living standards of the population (Milenković et al., 2017). Due to the obvious economic benefits of its development, tourism has long captured the attention of national governments and individuals (Luo, 2018). By adopting touris mdevelopment strategies, national governments seek to maximize the economic benefits of tourism. In order to adopt an adequate strategy, it is necessary to get acquainted with the current situation in tourism.

According to Menicucci (2018) "it is well accepted that the tourism industry is a major source of income for many developed and developing countries and is one of the most profitable service industries. In fact, many studies consider tourism as one of the main elements of economic expansion" (p. 2845). The performance of a hotel is relevant for "stakeholders such as creditors, owners, managers and employees" (Lado-Sestayo \& VivelBúa, 2018, p. 455).

One of the important as pects is to get acquainted with the existing financial performance of hotelcompanies. In other words, it is necessary to meas ure the financial performance of the company, because according to Krstić and Sekulić (2014) it is not possible to manage something that cannot be measured. As Haktanir (2006) states, the term "performance measurement", as an important component of the management process, has been in use for many years, gaining its popularity with the development of new management accounting techniques in 1990s. "Measurement should not be a goal for itself; it must have some meaning - it should indicate the quality of achieving the goals as well as the ability (or inferiority) of the company in achieving the given goals" (Todorović et al., 2015, p. 46). As a systemic procedure, performance measurement should help the company achieve the set goals (Chen et al., 2011). These performances can be viewed in a narrower sense when they are focused only on the profitability of the company, and in a broader sense, when in addition to profitability, it is necessary to consider the liquidity, activity and solvency of the company (Bogićević \& Stojanović, 2014). To test the financial performance of companies, ratio analysis is employed as a commonly used technique. Ratio analysis is defined as "the systematic use of indicators to interpret financial statements so that the strengths and weaknesses of an enterprise can be identified, as well as its historical performance and current financialcondition"(Divyesh, 2014, p. 32). Ratios are a very useful tool that allows management to take quick and appropriate action. They express connections and facilitate the study of correlations in a given numerical data (Diakomihalis, 2011). Since profitability in the company's operation is one of the conditions for its long-term survival and success in the market (Yazdanfar, 2013), it is necessary to constantly conduct profitability 
measurement. As Pavlović et al. (2020) claim, the realization of a higher value of profitability ratios compared to the previous period indicates that there has been an improvement in the financial situation of the company.

For profitability measurement in this paper, the ratio of profitability indicators was used, focusing on operating profit rate, net profit rate, rate of return on as sets (ROA) and rate of return on equity (ROE). The subject of this paper is to examine the level of profitability of hotel companies from the Republic of Serbia in the period from 2016 to 2019. The aim of this paper is to indicate the level of profitability of hotel companies from the Republic of Serbia, as well as to identify tendencies in the level of profitability trends.

The paper is structured from multiple logically defined and connected units. After introductory considerations, the paper contains a review of the literature which presents the results of previous research on the business of hotel companies in the world and, in particular, the area of hotel companies in the Republic of Serbia. The third part presents the s ample structure, applied methodology and data. The results of the res earch and discussions are presented in the fourth part, while in the last part, the conclusions of the conducted research are given, as well as several limitations in the research from which the possible directions of future research arise.

\section{Literature review}

Year afteryear, the profitability of hotel companies all over the world is examined both in different countries individually and through a series of comparative analyses of the trends of profitability ratios among different countries. Profitability is an important aspect of performance appraisal and evaluation that indicates the ability of a company to perform various tasks in the most efficient way (Divyesh, 2014). In order to survive and achievelongterm financial sustainability, hotel companies must strive to increase their profitability. Determinants of profitability in hotel companies have been studied from different perspectives and in different economies. Both the external and internal factors and characteristics related to hotel policy management were investigated. Some research has confirmed that "external factors such as the economic cris is, government policy, economic growth, politicalsituation, terrorist attacks and other economic and non-economic factors affect the performance and profitability of hotel companies" (Dimitrić, et al., 2019, p. 1985). The results of the research by Sami and Mohamed (2014) confirm that the financial performance of a hotel is related to the economic performance that is assessed by its technical efficiency. According to Bai and Buvaneshwaran (2015), "the hotel industry is a mature indus try marked by intense competition. The increase in market share usually comes at the expense of a competitor" (p. 138). In such circums tances, the importance of measuring profitability and comparing it with key competitors is even more emphasized.

Ryu and Jang (2004) measured the performance of commercial and casino hotels in the United States using traditional ratios and ratios based on cash flows, with the research covering their business from 1998 to 2002 . The res earch found that during the observed fiveyear period, casino hotels had a higher degree of liquidity, solvency and profitability compared to commercial hotels, with only a statis tically significant difference found in the general liquidity ratio and reduced liquidity ratio. Roška and Kuvačić (2018) monitored the liquidity and solvency of 26 hotel companies whose securities were listed on the Zagreb Stock Exchange, observing their values in 2008, 2012 and 2017. The research established that the observed companies increased their liquidity and solvency in 2017 compared to 2012 and 2008. 
Ais sa and Goaied (2016), with the help of Data Envelopment Analysis (DEA) and Return on Assets (ROA), analysed the profitability on a sample of 27 hotel companies from Tunisia. This research results point to the fact that managerial efficiency is important when geographic and operational contracts are constantly held. Nevertheless, these two as pects have important implications for hotel profitability. Hotel size, level of indebtedness, exposure to crisis events and level of education of managers were also highlighted as significant factors. A study by O'Neill and Mattila (2006) on a sample of more than 1,900 US hotels during 2002 and 2003 showed that the percentage of the hotels' net operating income was most closely related to the occupancy, although the average daily rate (ADR) had a strong influence, as well as a market segment (also known as chain scale), age of assets and brand affiliation. Sandvik et al. (2014) study, based on the data from the financial reports, covering the sample of 298 hotels, shows that the relationship between innovation and profitability is positive.

Mašić (2013) examined the performance of hotel companies operating in Serbia in the period from 2004 to 2011, with the analysis covering about $31.35 \%$ of the totalnumber of available capacities in the hotel industry. For the needs of performance testing, TREVPAR and GOPPAR indicators were used, and they were observed at the state level, within tourism clusters, as well as in the largest cities in Serbia. The research established that the observed hotel companies achieve low values of both indicators, while due to the economic cris is since 2008 there has been a significant decline in value. Further, it was determined that hotel companies based in Belgrade achieved significantly higher results compared to the national average, while the highest increase in the observed period was recorded in h otel companies in Kragujevac. Based on data from the financial reports for 2013, Borovčanin (2015) conducted a comparative analysis of the financial performance of 4 hotels ( 2 operate within international hotel chains, while 2 operate independently) in Belgrade. According to the author, there is a significant difference among the observed hotel companies between liquidity, financial structure, efficiency and profitability, although these are hotels that belong to the same category, have approximately the same number of rooms and are oriented towards the same or similar market segment. Having conducted the research on the sample of 60 hotel companies that gravitate to urban tourism, Jovanović et al. (2015) came to the conclusion that investments in selected projects did notbring a satis factory rate of retum, and that these investments in some years cannot cover interest costs. The authors state a high degree of indebtedness and inadequate allocation of capital as common characteristics of the observed companies. The reasons for the negative trend in the business of these companies can be external (globaleconomic cris is, low living standards, underdeveloped infrastructure and insufficient incentives from the state) and internal (lack of vision, skills and expertise of management, incomplete restructuring of tourism companies, inadequate skills and profes sionalismof employees and business without respecting quality standards). Radović and Stanić (2016) conducted an analysis of the profitability of twenty 4- and 5-star hotel companies in the period from 2010 to 2015 . In all 4 selected profitability indicators (operating profit rate, net profit rate, ROA and ROE), significant fluctuations in values were observed, which occurs as a consequence of the realized operating loss in some of the observed companies. The authors point out that the reasons for the adverse results in hospitality companies' operation are high fixed costs faced by hotel companies, indebtedness, economic cris is, and low-capacity utilization, which directly affects the level of income. According to Milosavljević et al. (2017), who have analysed the main drivers of the profit margin in the hotel sector in Belgrade, the tourismand hotel industry has attracted immense attention frommany stakeholders. The results of the conducted research indicate that the perception of customers is the most important factor that drives the financial performance of a hotel. Mitrović et al. (2019) analysed the liquidity of companies whose shares are traded on the Belgrade Stock Exchange, and which according to the sector 
classification are classified in Sector I - Accommodation and food services. The research found that most of the observed companies are characterized by the low value of used liquidity ratios (general liquidity ratio, reduced liquidity ratio, cash liquidity ratio and liquidity ratio based on net cash flow), i.e. liquidity ratios are below reference values, and there is a negative value of net working capital.

For the purposes of the paper's subject, it is important to point out the possibility of bankruptcy of hotel companies. In order to examine the possibility of bankruptcy in hotel companies from Serbia, Mizdraković et al. (2015) applied several models. The business of hotelcompanies was observed in the period from 2008 to 2012. It was found that from 2008 to 2011 there was a significant deterioration in the financial health of the observed companies, with the highest ris k of bankruptcy recorded in 2011. After that, i.e. during 2012, the financial health of the observed hotel companies improved. Milašinović et al. (2019) dealt with the possibility of bankruptcy in 7 hotel companies from the Belgrade Stock Exchange. Those are hotel companies whose market capitalization is higher than 100 million RS dinars. Altman's Z-score model was applied, which is adapted for companies operating in emerging markets, with the research covering the business of hotel companies from 2014 to 2018. Thus, in 2014, there were 3 companies in the "safe zone", 1 in the "grey" and 2 in the "problemzone", whereas in 2018, 3 companies were in the "s afe" and 3 in the "grey zone". It is important to note that one hotel company in the first four observed years had a loss above the amount of equity, which would automatically position it in the "problem zone", thus the application of the model for assessing financial health would have no practical significance.

\section{Methodology and data}

The profitability analysis was performed on a sample of 100 hotel companies based in the Republic of Serbia that achieved the highest operating revenue. These are companies whose activity code is 5510 - Hotels and similar accommodation (see The Government of the Republic of Serbia, 2010). The structure of the s ample from the as pect of size and legal form of the observed companies is shown in Table 1. The financial reports of the companies that were publicly available on the official internet presentation of The Business Registers Agency of the Republic of Serbia (2020) on August 1, 2020 were used as data sources for the analysis. For the needs of the paper, the data were taken from the mentioned reports for 2016, 2017, 2018 and 2019. Data on the balance of total assets and equity for the end of 2015, which are required when calculating the rate of return on total as sets and the rate of return on equity for 2016, are taken from the balance sheet for 2016 based on the comparative data for the final state of the previous year.

Table 1: Sample structure in terms of company size and legal form

\begin{tabular}{|c|c|}
\hline Size $^{*}$ & Number of companies \\
\hline Micro & 8 \\
\hline Small & 71 \\
\hline Medium & 21 \\
\hline Large & 0 \\
\hline Total & 100 \\
\hline Legal form & 12 \\
\hline stock company & 88 \\
\hline limited liability company & 100 \\
\hline Total & \\
\hline
\end{tabular}

Note: 'In the 2019, the classification was performed according to the Accounting Act from 2013

Source: Authors, based on data from the official internet presentation of The Business Registers Agency of the Republic of Serbia (2020) 
The profitability of hotel companies from the Republic of Serbia in the observed three-year period was measured with the following indicators: operating profit rate, net profit rate, return on total assets and rate of return on equity. The method of their calcu lation is shown in the following table.

Table 2: Profitability ratios of hotel companies

\begin{tabular}{|c|c|}
\hline Profitability ratios & Method of calculation \\
\hline Operating profit rate & (Operating result/Sales revenue) $^{*} 100$ \\
\hline Net profit rate & (Net result/Sales revenue)*100 $^{*}$ (Operating result/Average as sets) 100 \\
\hline Rate of return on total as sets (ROA) & (Net result/Average equity)*100 \\
\hline Rate of return on equity (ROE) & (20)
\end{tabular}

Source: Authors, adapted from Knežević et al. (2019)

Heikal et al. (2014) state that "ROE and ROA indicators, together with other financial performance indicators or looking at themindividually, each shape the growth rate achieved by the company" (p. 101). ROA can make it easier and enhance the achievement of the company's goals (Rico, 2006). He points out that the value of the ROA indicator can match the size of the company, which would mean a higher value indicator for larger companies. The ROA indicator can be very useful as a management tool in controlling and rewarding employees at the subsidiary level, but this does not mean that the ROE indicator is not important for managers (Todorović \& Čupić, 2017).

Statisticalanalysis has been conducted in IBM SPSS Statistics Version 24. The results of descriptive statistics are presented below, as well as the results of Friedman's test. Friedman's test was used because the data applied in the analysis did not have a normal distribution. In the event that the Friedman's test determines that there is a statistically significant difference that occurs somewhere between the three observed years, it is neces sary to conduct subsequent tests comparing the years of interest. Subsequent testing includes individual Wilcoxon's rank tests, with Bonferroni alpha correction to avoid type I error. When calculating Bonferroni's correction, we start from the initial level of significance (that is 0.05 ) and divide it by 3 , since the level of profitability of subsequent year is compared to that of the preceding one, i.e. the level of profitability in 2017 is compared to that of 2016, the one achieved in 2018 is compared to the one of 2017 and the one from 2019 is compared to that of 2018). In this way, a new level of significance of 0.017 is obtained (Pallant, 2007).

\section{Results and discussion}

The results of the research are presented at the level of the sample and at the level of individual hotel companies. Table 3 shows the trends of the operating profit rate of hotel companies in the period from 2016 to 2019 in the Republic of Serbia.

Table 3: Trends in the operating profit rate of hotel companies

\begin{tabular}{|l|c|c|c|c|}
\hline \multicolumn{1}{|c|}{ Elements } & $\mathbf{2 0 1 6}$ & $\mathbf{2 0 1 7}$ & $\mathbf{2 0 1 8}$ & $\mathbf{2 0 1 9}$ \\
\hline $\begin{array}{l}\text { Totaloperating result (in millions of } \\
\text { dinars) }\end{array}$ & 1,665 & 2,199 & 1,962 & 1,772 \\
\hline $\begin{array}{l}\text { Total sales revenues (in millions of } \\
\text { dinars) }\end{array}$ & 15,453 & 17,862 & 18,265 & 17,779 \\
\hline Sample of operating result rate & $10.78 \%$ & $12.31 \%$ & $10.74 \%$ & $9.97 \%$ \\
\hline $\begin{array}{l}\text { Average operating profit rate at the } \\
\text { sample level }\end{array}$ & $0.15 \%$ & $6.27 \%$ & $5.92 \%$ & $5.06 \%$ \\
\hline
\end{tabular}




\begin{tabular}{|l|c|c|c|c|}
\hline $\begin{array}{l}\text { Minimum rate of operating profit at the } \\
\text { sample level }\end{array}$ & $-498.05 \%$ & $-86.78 \%$ & $-105.89 \%$ & $-97.93 \%$ \\
\hline $\begin{array}{l}\text { Maximum operating profit rate at the } \\
\text { sample level }\end{array}$ & $53.42 \%$ & $42.07 \%$ & $36.86 \%$ & $94.44 \%$ \\
\hline $\begin{array}{l}\text { Number of companies with a negative } \\
\text { operating result }\end{array}$ & 18 & 18 & 23 & 23 \\
\hline $\begin{array}{l}\text { Number of companies with a positive } \\
\text { operating result }\end{array}$ & 82 & 82 & 77 & 77 \\
\hline
\end{tabular}

Source: Author's research

Table 3 shows that the sum of operating results of the observed hotel companies at the sample level is positive in all four years, with the change in the observed period. Namely, in 2017 , there was an increase in the total operating result by $32 \%$ compared to the previous year, and in 2018 and 2019, there was a decrease compared to 2017. When it comes to the total sales revenues of the observed hotel companies, there is a positive trend in their movement in the first three observed periods. Since the sum of operating results of the companies in the sample is positive in all four observed years, the rate of business profit at the level of the sample will also have positive values. Regarding the rate of operating profit at the sample level, variations in its value are noticeable. In 2017, the observed hotel companies at the level of the sample generated 12.31 dinars of operating profit for every 100 RS dinars of sales revenue, while in 2016 they realized 10.78 RS dinars. However, the increase did not continue in 2018 and 2019, since the operating profit rate was at a lower level compared to 2016. The trend of the value of the average operating result rate at the sample level is identical to the movement of the value of the operating result rate at the sample level (an increasing trend in 2017 compared to 2016, but a decreasing one in 2018 and 2019 compared to 2017). These oscillations occur due to significant changes in o perating results during the observed years. In the case of 48 companies, the operating profit rate decreased in 2017 compared to 2016, while 52 companies achieved a higher operating profit rate. Sixty-seven companies in 2018 achieved a lower rate of operating profit compared to 2017, while in the case of 33 companies there was an increase in the rate of operating profit. The operating profit rate of 35 companies is higher in 2019 than in 2018, while there was a decrease in 65 companies. The results of the conducted Friedman's test $\left(\chi^{2}(3, \mathrm{n}=100)=\right.$ $10,020 ; p=0,058)$ indicate that changes in the operating result rate of the observed individual hotel companies during the observed time are statistically significant (since $p>$ $0.05)$.

The following table shows the trend of the operating profit rate of hotel companies in the period from 2016 to 2019 in the Republic of Serbia.

Table 4: The trend of the net profit rate of hotel companies

\begin{tabular}{|l|c|c|c|c|}
\hline \multicolumn{1}{|c|}{ Elements } & $\mathbf{2 0 1 6}$ & $\mathbf{2 0 1 7}$ & $\mathbf{2 0 1 8}$ & $\mathbf{2 0 1 9}$ \\
\hline Totalnet result (in millions of dinars) & 355 & 2,528 & 1,705 & 1,653 \\
\hline $\begin{array}{l}\text { Total sales revenues (in millions of } \\
\text { dinars) }\end{array}$ & 15,453 & 17,862 & 18,265 & 17,779 \\
\hline Rate of net results at the sample level & $2.30 \%$ & $14.15 \%$ & $9.34 \%$ & $9.30 \%$ \\
\hline $\begin{array}{l}\text { Average net profit rate at the sample } \\
\text { level }\end{array}$ & $-9.11 \%$ & $8.32 \%$ & $4.81 \%$ & $-1.86 \%$ \\
\hline $\begin{array}{l}\text { Minimum rate of net profit at the } \\
\text { sample level }\end{array}$ & $-731.23 \%$ & $-80.13 \%$ & $-161.94 \%$ & $-511.87 \%$ \\
\hline $\begin{array}{l}\text { Maximum rate of net profit at sample } \\
\text { level }\end{array}$ & $288.57 \%$ & $256.38 \%$ & $108.42 \%$ & $68.59 \%$ \\
\hline
\end{tabular}


Mitrović, A. et al. - Profitability analysis of hotel companies in the Republic of Serbia-

Hotel and Tourism Management, 2021, Vol. 9, No. 1: 121-134.

\begin{tabular}{|l|c|c|c|c|}
\hline $\begin{array}{l}\text { Number of companies with a negative } \\
\text { net result }\end{array}$ & 19 & 12 & 15 & 20 \\
\hline $\begin{array}{l}\text { Number of companies with a positive } \\
\text { net result }\end{array}$ & 81 & 88 & 85 & 80 \\
\hline
\end{tabular}

Source: Author's research

The total sum of net results of companies included in the survey is positive in all four observed years, with a significant increase in 2017 compared to 2016, while in 2018 and 2019 there was a decrease in value compared to 2017. These oscillations were also reflected in the changes in the value of the net result rate at the level of the sample in the observed years, i.e. in 2017 there was an increase in the net result rate compared to 2016, while in 2018 and 2019 there was a decrease in the rate in compared to 2017. The rate of net results at the sample level recorded the highest value in 2017, companies at the sample level made a net profit of $14.15 \mathrm{RS}$ dinars per $100 \mathrm{RS}$ dinars of sales revenue. In the case of 47 companies, a lower net profit rate was recorded in 2017 compared to 2016 (53 companies recorded a higher net profit rate), while in 2018, 61 companies achieved a lower net profit rate compared to 2017, i.e. 37 companies achieved a higher net profit rate. In 2019, 56 hotel companies achieved a lower net profit rate compared to 2018, i.e. 44 achieved a higher net profit rate. Based on the conducted Friedman's test $(\chi 2(3, n=100)=5,532 ; p=0,137)$, it can be concluded that changes in the net profit rate during the observed years are not statis tically significant (because $\mathrm{p}>0.05$ ).

Table 5 shows the trend of the rate of return on total as sets of hotel companies in the period from 2016 to 2019 in the Republic of Serbia.

Table 5: The trend of the rate of return on total assets of hotel companies

\begin{tabular}{|l|c|c|c|c|}
\hline \multicolumn{1}{|c|}{ Elements } & $\mathbf{2 0 1 6}$ & $\mathbf{2 0 1 7}$ & $\mathbf{2 0 1 8}$ & $\mathbf{2 0 1 9}$ \\
\hline $\begin{array}{l}\text { Total operating result (in millions of } \\
\text { dinars) }\end{array}$ & 1,665 & 2,199 & 1,962 & 1,772 \\
\hline $\begin{array}{l}\text { Total funds at the beginning of the year (in } \\
\text { millions of dinars) }\end{array}$ & 72,302 & 73,459 & 76,922 & 80,057 \\
\hline $\begin{array}{l}\text { Total funds at the end of the year (in } \\
\text { millions of dinars) }\end{array}$ & 73,459 & 76,922 & 80,057 & 80,595 \\
\hline $\begin{array}{l}\text { The average value of total as sets (in } \\
\text { millions of dinars) }\end{array}$ & $72,880.5$ & $75,190.5$ & $78,489.5$ & 80,326 \\
\hline $\begin{array}{l}\text { The rate of return of total assets at sample } \\
\text { level }\end{array}$ & $2.28 \%$ & $2.92 \%$ & $2.50 \%$ & $2.21 \%$ \\
\hline $\begin{array}{l}\text { The average rate of return on total as sets at } \\
\text { the sample level }\end{array}$ & $6.17 \%$ & $6.43 \%$ & $5.74 \%$ & $4.47 \%$ \\
\hline $\begin{array}{l}\text { Minimum rate of return on total as sets at } \\
\text { the sample level }\end{array}$ & $-8.08 \%$ & $-36.63 \%$ & $-11.37 \%$ & $-15.43 \%$ \\
\hline $\begin{array}{l}\text { Maximum rate of return on total as sets at } \\
\text { sample level }\end{array}$ & $100.90 \%$ & $99.33 \%$ & $75.18 \%$ & $85.93 \%$ \\
\hline $\begin{array}{l}\text { Number of companies with a negative rate } \\
\text { of return on totalas sets }\end{array}$ & 18 & 18 & 23 & 23 \\
\hline $\begin{array}{l}\text { Number of companies with a positive rate } \\
\text { of return on totalas sets }\end{array}$ & 82 & 82 & 77 & 77 \\
\hline
\end{tabular}

Source: Author's research 
Based on the results shown in Table 5, there is a noticeable increase in the rate of return on total as sets at the sample level in 2017 compared to the previous year. In 2018 and 2019, there was a decrease in the rate of return on total as sets at the sample level compared to 2017. Trends in the movement of the average rate of return on total as sets at the sample level are identical to the trend in the rate of return on total assets at the sample level (an upward trend followed by a downward trend). In 2017, forty-two hotel companies achieved a lower return on total engaged funds compared to 2016, while 57 companies recorded an increase in the returns. In 2018, 67 companies achieved a lower rate of return on total ass ets compared to 2017 , and 32 companies saw an increase in it. The rate of return on total assets is lower in 63 companies in 2019 compared to 2018, i.e. higher in 37 companies. One hotel company achieved the same rate of return on total assets in first three observed years. Further, the maximum rates of return on total as sets $(100.90 \%$; $99.33 \% ; 75.18 \%$ and $85.93 \%$ ) were achieved by one company. The results of the Friedman's test show that there is a statistically significant difference between the rate of return on total assets in the four observed years $(\chi 2$ $(3, n=100)=17.434 ; p=0.001)$ (because $p<0.05)$. The average value of the rank recorded the highest value in 2017 (2.88), while the lowest value was recorded in 2019(2.15). Wilcoxon's rank test revealed a statis tically significant decrease in the rate of return on total as sets in 2018 compared to $2017(\mathrm{z}=-2.876 ; \mathrm{p}=0.004)$ with a small difference $(\mathrm{r}=0.20)$. The median rate of return on total assets decreased from $-\mathrm{Md}=29.87 \%$ in 2017 to $-\mathrm{Md}=28.56 \%$ in 2018. Changes in the rate of return on total as sets in 2017 compared to 2016, as well as changes in 2019 compared to 2018 are not statistically significant $(\mathrm{p}>0.017)$.

The trend of the rate of return on equity of hotel companies in the period from 2016 to 2019 in the Republic of Serbia is shown below (Table 6).

Table 6: The trends in the rate of return on equity of hotel companies

\begin{tabular}{|l|c|c|c|c|}
\hline \multicolumn{1}{|c|}{ Elements } & $\mathbf{2 0 1 6}$ & $\mathbf{2 0 1 7}$ & $\mathbf{2 0 1 8}$ & $\mathbf{2 0 1 9}$ \\
\hline Totalnet result (in millions of dinars) & 355 & 2,528 & 1,705 & 1,653 \\
\hline $\begin{array}{l}\text { Total equity at the beginning of the year } \\
\text { (in millions of dinars) }\end{array}$ & 44,512 & 44,699 & 48,710 & 49,570 \\
\hline $\begin{array}{l}\text { Total equity at the end of the year (in } \\
\text { millions of dinars) }\end{array}$ & 44,699 & 48,710 & 49,570 & 50,138 \\
\hline $\begin{array}{l}\text { The average value of equity (in millions } \\
\text { of dinars) }\end{array}$ & $44,605.5$ & $46,704.5$ & 49,140 & 49,854 \\
\hline Equity rate of return at sample level & $0.80 \%$ & $5.41 \%$ & $3.47 \%$ & $3.32 \%$ \\
\hline $\begin{array}{l}\text { Averagerate of return on equity at the } \\
\text { sample level }\end{array}$ & $17.24 \%$ & $16.09 \%$ & $10.49 \%$ & $13.36 \%$ \\
\hline $\begin{array}{l}\text { Minimum rate of return on equity at the } \\
\text { sample level }\end{array}$ & $-100.88 \%$ & $-39.82 \%$ & $-139.96 \%$ & $-212.48 \%$ \\
\hline $\begin{array}{l}\text { Maximum rate of return on equity at the } \\
\text { sample level }\end{array}$ & $199.53 \%$ & $113.61 \%$ & $155.53 \%$ & $603.43 \%$ \\
\hline $\begin{array}{l}\text { Number of companies with a negative rate } \\
\text { of return on equity }\end{array}$ & 19 & 12 & 15 & 20 \\
\hline $\begin{array}{l}\text { Number of companies with a positive rate } \\
\text { of return on equity }\end{array}$ & 81 & 88 & 85 & 80 \\
\hline
\end{tabular}

Source: Author's research

At the sample level, the observed hotel companies in 2017 achieved a higher return on equity compared to 2016, and in 2018 and 2019 there was a decline in the value of this indicator. 
The average rate of return on equity recorded a downward trend during the three observed years, with the decline being most significant in the last observed year. In 2017, 45 companies achieved a lower return on equity compared to the previous year, while 55 of themincreased their return on equity. The lower rate of return on equity in 2018 compared to 2017 was recorded in 68 companies, i.e. the higher rate of return on equity was achieved by 32 companies. The rate of return on equity is lower in 61 companies in 2019 than in 2018, and higher in 39 companies. The results of the Friedman's test $(\chi 2(3, n=100)=18.276$; $\mathrm{p}=0.000$ ) (because $\mathrm{p}<0.05$ ) indicate that the change in the rate of return on equity is statis tically significant in the observed four-year period. As with the rate of return on total assets, Wilcoxon's rank test revealed a statistically significant decrease in the rate of return on equity in 2018 compared to 2017 ( $\mathrm{z}=-3.548 ; \mathrm{p}=0.000)$, with a small difference $(\mathrm{r}=0.25)$ and a statis tically significant decrease in the rate of return on equity in 2019 compared to $2018(\mathrm{z}=-2.445 ; \mathrm{p}=0.014)$, with a small difference $(\mathrm{r}=0.21)$. The median rate of return on the own assets decreased by from- $\mathrm{Md}=3.94 \%$ in 2017 to $\mathrm{Md}=3.83 \%$ in 2018 , and the median rate of return on the own assets decreased by from-Md=3.83\% in 2018 to $\mathrm{Md}=3.29 \%$. Further, Wilcoxon's rank test found that changes in the rate of return on equity in 2017 compared to 2016 are not statistically significant ( $p>0.017$ ).

The summary of economic as sessment after the profitability testing indicates several things. When it comes to the business result and the net result, there are oscillations during the observed four-year period (first a growing trend, and then a decrease in value). In the observed period, there is a trend of growth in the value of assets and equity of hotel companies, which may indicate an increase in investments that are mostly finance $d$ from theirown sources of financing. Further, there is a decrease in the value of ROA and ROE indicators at the level of the sample and the level of individual companies. This may indicate that the observed hotel companies do not have adequatecapital productivity, and this should be carefully analysed in order to reach a more precise conclusion.

\section{Conclusion}

The research found that in the observed hotel companies there was an increase in the value of all four used profitability ratios (operating profit rate, net profit rate, rate of return on total assets and rate of return on equity) in 2017 compared to 2016, and in 2018 and 2019 there was a downfall of their values. In addition, the research found that the changes in operating profit rates and net profit rates during the observed period are not statistically significant, i.e. it cannot be claimed that hotel companies from the Republic of Serbia increased or decreased profitability in the observed four-year period. When it comes to the rate of return on total assets, it was found that in 2018 , there was a statistically significant decrease compared to 2017. When it comes to the rate of return on total equity, it was found that there was a statistically significant decrease in 2018 compared to 2017 and in 2019 compared to 2018. Moreover, it is necessary to mention that in the structure of the observed hotel companies from the Republic of Serbia during the observed four-year period, those companies that achieved positive profit rates (operating profit rates and net profit rates) and positive rates of return (rates of return on total as sets and rates of return on equity) have a higher share than those that recorded the negative ones. Des pite the small share of companies with negative (operating and net) results in the total number of observed companies, the losses they achieved were very large, which was reflected in significantly lower values of total operating and net results, and thus lower profitability rates at the sample level. The observed hotel companies in the period from 2016 to 2019 are also characterized by the growth of total funds, as well as equity. This may indicate an increase in investments, which are mainly financed from their own resources. 
The contribution of this study is to describe the leveland trend of hotels' profitability in the Republic of Serbia in the period before the COVID-19 pandemic. The scientific contribution of the study is reflected, additionally, in the existing, both foreign and domestic knowledge about the functioning of hotels. In addition to the contribution to the academic community, the results can be useful to the owners and the management of analy sed companies, in order to be introduced to the functioning of not only their company but also other companies that operate within the same area of activity. Moreover, the results allow potential investors to make the decision to invest in those companies that will bring them the highest return. The results can be useful foreconomic policy-makers to get introduced with the analysed hotel's functioning andbring adequate incentives that would results in business improvement, as well as for other stakeholders who are interested in the functioning of hotels. This research offers valuable information to identify strategic proposals for various stakeholders such as hotelinvestors, hotel owners, managers, touris m development creators and go vernment.

The conducted research also has several limitations from which the directions of future research arise. The first limitation is the short period of monitoring the operations of hotel companies due to the lack of publicly available financial reports of hotel companies. Therefore, in future research, we should try to monitor the operation for a longer period of time, with the possibility of forming a larger sample, which would increase the reliability and strength of the results. The limitations in the res earch are those that arise from the limitations of the ratio analysis itself (for more details, see Knežević et al., 2011). Since the research covers only the profitability of hotel companies, in order to gain a complete picture of the operation of companies from this industry, it is necessary to analyse their liquidity, solvency and activity. In addition to continuous monitoring of the level of profitability of hotel companies, it is neces sary to identify determinants (factors) that had an impact on the level of profitability in order for the manager of the company to make adequate decisions. For this reason, it is necessary to conduct research aimed at identifying the impact of internal and externaldeterminants on the level of profitability of hotel companies. In previous research, accounting measures (measures used in the paper) that are turned to the past are the most common as measures of company performance. Future research would focus on identifying factors that affect profitability, both operational and institutional. Further, future research could relate to the relationship between financial performance (measured ROA) and the growth of the observed companies. Therefore, in future research, it is necessary to focus more on market measures, measures based on cash flows and values (such as added market value and added economic value), as measures that are future-oriented. Further, the limitation stems fromthe data sources thems elves. Namely, the financial s tatements do not contain (or contain to a small extent) non-financial information (e.g. information on the quality of products/services, customer satisfaction, business flexibility, etc.) which are very important and necessary in the process of business decision-making, improving competitiveness, as well as improving financial performance (Janjić et al., 2015). Therefore, the same authors state that in order to get a clear picture of the achieved results of the company, in addition to financial performance measures, it is necessary to use the nonfinancial ones.

\section{Conflict of interest}

The authors declare no conflict of interest. 


\section{References}

1. Aissa, S. B., \& Goaied, M. (2016). Determinants of Tunisian hotel profitability: The role of managerial efficiency. Tourism Management, 52, 478-487. https://doi.org/10.1016/j.tourman.2015.07.015

2. Bai, B. K., \& Buvaneshwaran, V. (2015). A comparative study of profitability analy sis of selected hotel industries. International Journal of Applied Research, 1(9), 138-141.

3. Bogićević, J., \& Stojanović, D. (2014). Analiza finansijskih performansi javno komunalnih preduzeća u Kragujevcu [Analy sis of financial performance of public utility companies in Kragujevac]. In Lj. Maks imović \& N. Stanišić (Ed.), Stanje i perspektive ekonomskog razvoja grada Kragujevca (pp.457-468). Kragujevac, Srbija: Univerzitet u Kragujevcu, Ekonoms ki fakultet.

4. Borovčanin, D. (2015). A comparative analysis on hotel financial performance. SITCON 2015 - Competitiveness Factors of Tourism Enterprises (pp. 198-201). Belgrade, Serbia: Singidunum University. https ://doi.org/10.15308/sitcon-2015-198-201

5. Chen, F. H., Hsu, T. S., \& Tzeng, G. H. (2011). A balanced scorecard approach to establish a performance evaluation and relationship model for hot spring hotels based on a hybrid MCDM model combining DEMATEL and ANP. International Journal of Hospitality Management, $\quad 30(2011), \quad 908-932$. https://doi.org/10.1016/i.iihm.2011.02.001

6. Diakomihalis, M. N. (2011). Financial structure and profitability analysis of Greek hotels. The Journal of Hospitality Financial Management, 19(1), 5170. http://dx.doi.org/10.1080/10913211.2011.10653900

7. Dimitrić, M., Tomas Žiković, I., \& Arbula Blecich, A. (2019). Profitability determinants of hotel companies in selected Mediterranean countries. Economic Research Ekonomska Istraživanja, 32(1),

1977 1993. http://dx.doi.org/10.1080/1331677X.2019.1642785

8. Divyesh, D. S. (2014), Performance measurement through ratio analys is: The case of indian hotel company ltd. The IUP Journal of Management Research, 15(1), 30-37

9. Haktanir, M. (2006). Performance measurement in independent hotels. In P. Harris \& Mongiello, M. (Ed.), Accounting and Financial Management: Developments in the International Hospitality Industry (pp. 3-21). Oxford: Butterworth-Heinemann.

10. Heikal, M., Khaddaf, M., \& Ummah, A. (2014). Influence analysis of return on as sets (ROA), return on equity (ROE), net profit margin (NPM), debt to equity ratio (DER), and current ratio (CR), against corporate profit growth in automotive in Indonesia stock exchange. International Joumal of Academic Research in Business and Social Sciences, 4(12), 101-114.

11. Janjić, V., Todorović, M., \& Jovanović, D. (2015). A comparative analys is of modern performance meas urement and management models of companies. Economic Themes, 53(2), 303-318. https://doi.org/10.1515/ethemes -2015-0017

12. Jovanović, N., Jovanović, M., \& Jovanović, N. (2015). Evaluation of financial capacity of hotel enterprises gravitating to urban tourism centers in the Republic of Serbia. SITCON 2015 - Competitiveness Factors of Tourism Enterprises (pp. 168-174). Belgrade, Serbia: SingidunumUniversity. https://doi.org/10.15308/sitcon-2015-168-174

13. Knežević, S., Barjaktarović-Rakočević, S., \& Đurić, D. (2011). Implementation and restraints of ratio analysis of financial reports in financial decision making. Management - Journal for Theory and Practice Management, 16(61), 25-31.

14. Knežević, S., Mitrović, A., Vujić, M., \& Grgur, A. (2019). Analiza finansijskih izveštaja [Financial statement analysis]. Beograd, Srbija: Samostalno izdanje autora.

15. Krstić, B., \& Sekulić, V. (2013). Upravljanje performansama preduzeća [Enterprise performance management] (2nd ed.). Niš: Ekonoms ki fakultet Univerziteta u Nišu. 
16. Lado-Sestayo, R., \& Vivel-Búa, M. (2018). Profitability in the hotel sector: A PLS approach. Journal of Hospitality and Tourism Technology, 9(3), 455470. https://doi.org/10.1108/JHTT-10-2017-0118

17. Lee, Y. L., Kuo, S. H., Jiang, M. Y., \& Li, Y. (2019). Evaluating the performances of Taiwan's international tourist hotels: Applying the directional distance function and meta-frontier approach. Sustainability, 11(20), 5773, https://doi.org/10.3390/su11205773

18. Luo, W. (2018). Evaluating tourist destination performance: Expanding the sus tainability concept. Sustainability, 10(2), 2766. http://dx.doi.org/10.3390/su 10020516

19. Mašić, I. S. (2013). The performance of the Serbian Hotel Industry. Singidunum Journal of Applied Sciences, 10(2), 24-31. https ://doi.org/10.5937/s jas 10-4481

20. Menicucci, E. (2018). The influence of firm characteristics on profitability: Evidence from Italian hos pitality industry. International Journal of Contemporary Hospitality Management, 30(8), 2845-2868. https://doi.org/10.1108/IJCHM-04-2017-0219

21. Milašinović, M., Knežević, S., \& Mitrović, A. (2019). Bankruptcy forecasting of hotel companies in the Republic of Serbia using Altman's Z-score model. Hotel and Tourism Management, 7(2), 87-95. https://doi.org/10.5937/menhottur1902087M

22. Milenković, N., Andrašić, J., \& Kalaš, B. (2017). Financial analysis of the tourism sector - The example of catering enterprises of Northern Vojvodina. Second International Thematic Monograph - Thematic Proceedings: Modern Management Tools and EconomyofTourism Sector in Present Era (pp. 197-212). Belgrade, Serbia: As sociation of Economists and Managers of the Balkans in cooperation with the Faculty of Tourism and Hospitality, Ohrid, Macedonia.

23. Milosavliević, M., Milanović, N., \& Benković, S. (2017). Antecedents of hotel profitability: Empirical evidence fromBelgrade. Management: Journal of Sustainable Business and Management Solutions in Emerging Economies, 21(81), 77-85. https://doi.org/10.7595/management.fon.2016.0031

24. Mitrović, A., Knežević, S., \& Milašinović, M. (2019). Analys is of the cash flow ratios and traditional liquidity ratios of hotel companies in the Republic of Serbia. KNOWLEDGE - International Journal, 35(1), 71-76.

25. Mizdraković, V., Knežević, G., \& Stanić, N. (2015). Bankruptcy risk exposure of Serbian hotels in the period 2008-2012. SITCON 2015 - Competitiveness Factors of Tourism Enterprises (pp. 164-167). Belgrade, Serbia: Singidunum University. https://doi.org/10.15308/sitcon-2015-164-167

26. O'Neill, J. W., \& Mattila, A. S. (2006). Strategic hotel development and positioning: The effects of revenue drivers on profitability. Cornell Hotel and Restaurant Administration Quarterly, 47(2), 146-154.

27. Pallant, J. (2007). SPSS survival manual: A step by step guide to data analysis using SPSS for Windows (Version 15) (3rd ed.). Berks hire, UK: Open University Press.

28. Pavlović, M., Radoičić, J., \& Milanović, M. (2020). Profitability analys is of apple production in the Republic of Serbia. Economics of Agriculture, 67(3), 817-830. https://doi.org/10.5937/ekoPolj2003817P

29. Radović, N., \& Stanić, N. (2016). The analys is of profitability in management of hotel enterprises. Finiz 2016 - Risks in Contemporary Business (pp. 171-174). Belgrade, Serbia: Singidunum University. https://doi.org/10.15308/finiz-2016-171-174

30. Ren, T., Can, M., Paramati, S. R., Fang, J., \& Wu, W. (2019). The impact of tourism quality on economic development and environment: Evidence from Mediterranean countries. Sustainability, 11(8), 2296. https://doi.org/10.3390/su11082296

31. Rico, F. D. (2006). A framework for measuring ROI of enterprise architecture. Journal of Organizational and End User Computing , 18(2), 1-12.

32. Roška, V., \& Kuvačić, D. (2018). Analys is of financial strength and liquidity of listed companies in tourism sector in Croatia. 3rd International Thematic Monograph - 
Thematic Proceedings: Modern Management Tools and Economy of Tourism Sector in Present Era (pp.327-340). Belgrade, Serbia: As sociation of Economists and Managers of the Balkans in cooperation with the Faculty of Tourism and Hospitality, Ohrid, Macedonia.

33. Ryu, K., \& Jang, S. (2004). Performance measurement through cash flow ratios and traditional ratios: A comparison of commercial and cas ino hotel companies. The Journal of Hospitality Financial Management, 12(1), 15-25.

34. Sami, B. A., \& Mohamed, G. (2014). Determinants of tourism hotel profitability in Tunisia. Tourism and Hospitality Research, 14(4), 163-175, https://doi.org/10.1177/1467358414543970

35. Sandvik, I. L., Duhan, D. F., \& Sandvik, K. (2014). Innovativeness and profitability: An empirical investigation in the Norwegian hotel industry. Cornell Hospitality Quarterly, 55(2), 165-185. https://doi.org/10.1177/1938965514520963

36. The Business Registers Agency of the Republic of Serbia (2020). Searches. Retrived July 01, 2020 from https://www.apr.gov.rs/

37. The Government of the Republic of Serbia (2010). Classification of activities. Official Gazette RS, No. 54/2010.

38. Todorović, M., \& Čupić, M. (2017). How does 5s implementation affect company performance? A case study applied to a subsidiary of a rubber goods manufacturer from Serbia. Engineering Economics, 28(3), 311-322. http://dx.doi.org/10.5755/j01.ee.28.3.16115

39. Todorović, M., Kaličanin, Đ., \& Nojković, A. (2015). Practices of performance measurement in companies in the Republic of Serbia. Economic Horizons, 17(1), 45-59. https://doi.org/10.5937/ekonhor1501045t

40. Yazdanfar, D. (2013). Profitability determinants among micro firms: Evidence from Swedish data. The International Journal of Managerial Finance, 9(2), 150-160.

Received: 1 January 2021; Sent for revision: 15 February 2021; Accepted: 6 June 2021 